\title{
The Printing of English Narratives in Wynkyn de Worde's Later Career
}

\begin{abstract}
In the course of his long career, the London printer Wynkyn de Worde produced editions of English narratives of different kinds. Although these constitute a relatively small part of his total output, they nonetheless suggest that he took some interest in developing titles involving romance and "merry jest", and his attention to these genres in the early and middle part of his career has been the subject of productive scholarship. This essay surveys evidence from the later years of de Worde's career. It investigates the extent to which he concerned himself with new titles or with reprints of works of this kind and looks for signs of experimentation in the ways they were presented (taking account of title-pages and the provision of woodcuts, for example). It pays particular attention to the novelle and jests, as well as to indications that the printing of some of these English tales were in response to particular circumstances.
\end{abstract}

Au cours de sa longue carrière, l'imprimeur londonien Wynkyn de Worde a produit des éditions de plusieurs genres narratifs anglais. Bien que ceux-ci ne constituent qu'une partie relativement restreinte de sa production totale, il semble néanmoins que l'imprimeur londonien ait vraiment tenté de constituer un fonds composé de romans et de contes à rire. L'attention que Wynkyn de Worde a portée à ces genres au début et au milieu de sa carrière a déjà fait l'objet de recherches abondantes. Cet article étudie les dernières années de sa carrière. En particulier, il tente de discerner dans quelle mesure de Worde est lui-même responsable du choix de nouveaux titres ou de titres à réimprimer, et décrit aussi dans quelle mesure l'imprimeur londonien a introduit des innovations au niveau de la présentation (les pages de titre ou les gravures sur bois, par exemple). L'article consacre beaucoup d'attention aux novelle et aux histoires comiques, et à des signes qui pourraient indiquer que l'impression de certains textes s'est faite en réponse à des circonstances particulières.

Wynkyn de Worde had a long career as one of England's major early printers. Starting work with William Caxton at Westminster, he took on Caxton's business after his death in 1492 and evidently remained actively at work until his own death in $1534 / 5$. $^{1}$ This career of over forty years, during the

1 N. F. Blake, 'Wynkyn de Worde: the Early Years'. In: Gutenberg Jahrbuch (1971), p. 62-69; N. F. Blake, 'Wynkyn de Worde: the Later Years'. In: Gutenberg Jahrbuch (1972), p. 128-138; Mary C. Erler, 'Wynkyn de Worde’s Will: Legatees and Bequests'. In: The Library, 6th ser., 10 (1988), p. 107-121. His connection with Caxton was made prominent in most of the printers' marks he used (see the examples in R. B. McKerrow, Printers` and Publishers` Devices in England and

Julia Boffey, Queen Mary University of London

Ә Open Access. (C) 2019 Julia Boffey, published by De Gruyter. (cc) BY-NC-ND This work is licensed under a Creative Commons Attribution-NonCommercial-NoDerivatives 4.0 International License.

https://doi.org/10.1515/9783110563016-005 
early part of which (in 1501) he moved the business from Westminster to the city of London, saw the printing of around 850 titles. $^{2}$ Although this figure includes multiple editions of some titles, especially significant in the case of schoolbooks which went through many editions, it is still a striking total; and still more so if, as has been calculated, around $70 \%$ of the works he printed were put in print by him for the first time. The books he printed included many works a long way from narrative literature: not just the grammars and schoolbooks in which he came to specialize, but also indulgences, works for priests and treatises of spiritual instruction; many of these were Latin works. His total output includes only somewhere around forty to fifty titles that fall into the category of 'narrative literature' in the vernacular, in prose or verse. ${ }^{3}$ But for over four decades Wynkyn de Worde was one of the main printers of such materials in England, with an output in this area rivalled only by that of Richard Pynson ${ }^{4}$; and his innovations in this field were significant.

The activities of De Worde's early years as a printer, including innovations made in the fields of type and woodcut illustration, have been exhaustively documented by Lotte Hellinga. ${ }^{5}$ Some of the preoccupations of his first decades in London, after 1501, are explored in Martha Driver's work on the appearance of the books he printed, particularly his experiments with the design possibilities of the printed page and with the commercial potential of illustration and other design features. ${ }^{6}$ Driver notes De Worde's cultivation of a 'brand' through the standardization of certain features of his books and his ready exploitation of factotum figures

Scotland, 1485-1640. London 1913). [For De Worde, see also the contribution by Sánchez-Martí in the present volume, p. 143.]

2 This figure is derived from the information given in STC Vol. III, p.187-189, and is necessarily approximate (it includes reprinted titles and books printed for De Worde by others or using his types, for example). For analyses of De Worde's overall output, some of which are based on outdated assessments of the total number of books he printed, see H. S. Bennett, English Books \& Readers 1475 to 1557. Cambridge 1970 [1952], p. 190-192; James Moran, Wynkyn de Worde: Father of Fleet Street. Ed. by Lotte Hellinga and Mary C. Erler, with a preface by John Dreyfus. London 2003 [1976], p. 48-49; and Lotte Hellinga, William Caxton and Early Printing in England. London 2010, p. 131-155.

3 For the purposes of this discussion, 'narrative literature' is taken to include romances in prose and verse; entertaining stories, variously comic and exemplary; novelle in English. Categories that have been excluded are dream visions (by authors including Chaucer, Lydgate, Skelton, Hawes and Neville), debates and love complaints.

4 On Pynson, see Pamela Neville-Sington, 'Pynson, Richard (c.1449-1529/30)'. In: ODNB, online ed., Jan 2008 [http://0-www.oxforddnb.com.catalogue.libraries.london.ac.uk/view/article/22935].

5 See Moran, Wynkyn de Worde (note 2), p. 182-229.

6 Martha W. Driver, The Image in Print: Book Illustration in Late Medieval England and its Sources. London 2004, p. 77-114. 
in the forms of title-page that he favoured. Work by other scholars on De Worde's printing of English romances during these years has fleshed out the detail of De Worde's strategies in relation to these particular narratives, a 'line' which he seems quite deliberately to have developed in his first two decades in business and to the design of which he clearly paid attention. ${ }^{7}$ Carol Meale has written of the "continuing vitality" of the romance genre among the many works printed by De Worde, noting that the number of times that he reprinted individual romances attests to "a lively demand amongst the readers and buyers of books". 8

Most studies of the works printed by De Worde have concentrated on the early and middle part of his career, perhaps partly in order to clarify the new directions he took after Caxton's death, and to ascertain how his preoccupations differed from those of Richard Pynson, London's other major printer during the first decades of the sixteenth century. Certainly De Worde's most energetic cultivation of new markets seems to have taken place in the years before 1520, particularly with his publication of Latin schoolbooks by authors like John Stanbridge and Robert Whittinton; and these years also saw the first appearances of most of the Middle English narratives he printed - romances, verse narratives and short narrative 'jests' (comic stories, in prose and in verse) of various kinds. To some extent the range of works published in the years after 1520 until his death in 1535 might reasonably be characterized as unadventurous, dominated by reprints of established successes like the schoolbooks, which Lotte Hellinga has seen as a "cash crop" forming "a very significant proportion of his total output". But even though the number of narrative works published between 1520 and 1535 is not great, it is worth reviewing the degree to which these works do or do not replicate patterns established earlier in de Worde's working life and inspecting features of their presentation to see how elements of design may have played into their production and marketing. Such a review can serve to highlight the particularities of readers' tastes in narrative literature at this point and help to determine the extent to which these might have undergone changes over the course of De Worde's long career.

7 See especially Carol M. Meale, 'Caxton, de Worde and the Publication of Romance in Late Medieval England'. In: The Library 6th ser., 14 (1992), p. 283-298; Jordi Sánchez-Martí, 'The Printed History of Middle English Verse Romances'. In: Modern Philology 107 (2009), p. 1-31; and Jordi Sánchez-Martí, 'Illustrating the Middle English Verse Romances'. In: Word and Image 27 (2011), p. 90-102.

8 Meale, Caxton (note 7), p. 298.

9 Hellinga (see note 2), p. 153. 
Works of narrative literature printed by De Worde between 1520 and 1535 fall into three main categories. First are the reprints of romances, in both prose and verse, which De Worde had already published before 1520. These include Sir Bevis of Hampton (verse; [1500], STC 1987; [c.1500], STC 1987.5; [1533?], STC 1988.6); The Knyght of the swanne or Helyas (prose; 1512, STC 7571; c. 1522, STC 7571.5); Capystranus (verse; c. 1515, STC 14649; [?1527], STC 14649.5; [1530?], STC 14650); Kynge Rycharde cuer du lyon (verse; 1509, STC 21007; 1528, STC 21008); The dystruccyon of Iherusalem (prose; [1510?], STC 14518; 1528, STC 14519); Malory, Le Morte Darthur (prose; 1498, STC 802; 1529, STC 803); ye byrth \& prophecye of Marlyn (verse; 1499, STC 17840.7; 1510, STC 17841; 1529, STC 17841.3). Clearly these must have counted as reliable favourites of some kind and attention will be given below to the extent to which certain of them were revised or updated in any way as they were reprinted across the course of time.

In the second category are romances that were printed by De Worde for the first time in the years between 1520 and 1535, or which survive only in editions assigned on some form of evidence to these years. This group of works includes two which were printed only by De Worde and thus will merit some attention: Undo youre dore, also known in later editions as The Squire of Low Degree (verse; [c. 1520], STC 23111.5), and The life of Ipomydon (verse; [c. 1522], STC 5732.5; [c. 1527], STC 5733). A further 'new' romance for De Worde in these years, Sir Tryamour (verse; 1530, STC 24302), had been previously printed by Pynson and is accordingly slightly different. The third category of English narrative works printed by De Worde between 1520 and 1535 includes the tried and tested non-romance favourites the Gesta romanorum (prose; previously printed by De Worde [c.1502], STC 21286.2; [c. 1510], STC 21286.3; [c. 1515], STC 21286.5; [c. 1525], STC 21286.7) and Reynard the Fox (prose; c. 1525, STC 20192a), previously printed by Pynson ([1494], STC 20921; [before 1506], STC 20921.5), from Caxton's translation; two verse novelle based on stories by Boccaccio, in versions made by William Walter and apparently printed for the first time: ye hystory of Tytus \& Gesyppus (1525, STC 3184.5) and The amerous hystory of Guystard and Sygysmonde (1532, STC 3183.5); and finally a small clutch of short comic tales: Les faictz merueilleux de virgille (French prose; c. 1520, STC 24827.5); Skelton's The Tunning of Elinor Rumming (verse; [c.1521], STC 22611.5); a mery iest of the mylner of Abyngdon (verse; 1532-34: STC 78) and a lytell propre ieste called cryste crosse me spede (verse; c. 1534, STC 14546.5). These last two sorts of work - novelle and comic tales - will also come under scrutiny in what follows.

Before embarking on detailed study of all these titles there are some general observations to be made about what survives from these years of De 
Worde's career. Probably the most important of these points is one that relates to the survival patterns of all early books, which are inevitably patchy and may well be unrepresentative. Even what survives is often fragmentary, sometimes lacking first and last leaves which might have carried crucial information about matters like publication dates or authorship, and in some cases so depleted as to constitute very little in the form of hard evidence. All of this makes it something of a challenge to trace patterns or continuities or new departures, although one point that might be made about the English narratives printed by De Worde between 1520 and 1535 is that long works of 'literary' verse by authors like Chaucer and Lydgate are absent (at earlier points De Worde had printed Chaucer's Canterbury Tales and Troilus and Criseyde and Lydgate's Siege of Thebes, but he seems to have been uninterested in new editions). Another complicating feature of De Worde's later career is the increasing evidence for forms of collaboration with other printers, ventures which have the effect of blurring the outlines of what might have been his own initiatives during these years. The association of some vernacular narratives with De Worde's name may in fact owe more to the energies of collaborators like Robert Copland, who certainly shaped some texts for publication even if not suggesting them as new initiatives. Of the works listed in the paragraph above, at least three have associations of some kind with Copland: Ipomydon, The Knyght of the swanne and The amerous hystory of Guystard and Sygysmonde. ${ }^{10}$ Some of the younger printers acquiring business in London in the 1520s and 1530s had worked with De Worde or collaborated with him and their own ventures into the printing of English narratives may owe more than is now apparent to lost De Worde editions: John Skot, who had connections of some kind with De Worde, printed The hystory of syr Isembras c. 1530 (verse; STC 14280.5, frag.) and The jest of Sir Gawaine c. 1528 (verse; STC 11691a.3) and c. 1530 (verse; STC 11691a.5, this time in collaboration with John Butler, who had also worked for De Worde) ${ }^{11}$; after De Worde's death one of his former apprentices, John Byddell, produced his

10 For the verse by Copland added to Ipomydon and Guystard and Sygysmonde, see Mary C. Erler (ed.), Robert Copland: Poems. Toronto 1993, p. 76-77, 149-159. On his role in Ipomydon, see Jordi Sánchez-Martí, 'Wynkyn de Worde's Editions of Ipomydon: A Reassessment of the Evidence'. In: Neophilologus 89 (2005), p. 153-163; and Jordi Sánchez-Martí, 'Robert Copland and The Lyfe of Ipomydon'. In: Notes and Queries 55 (2008), p. 139-142.

11 On Skot and Butler, see STC Vol. III, p. 156 and p. 33; and Peter W. M. Blayney, The Stationers' Company and the Printers of London 1501-1557. 2 vols, Cambridge 2013, p. 179-180. 
own edition of Adam Bell (verse; 2 June 1536, STC 1806), printed at least once earlier in De Worde's career around 1505. ${ }^{12}$

\section{Reprinting Romances}

Rycharde cuer du lyon and Malory's Morte Darthur are examples of substantial romances printed by De Worde both early and late in his career. Comparison of the surviving editions offers the opportunity to assess the amount of energy that went into updating these works over time and to investigate evidence of any experimentation with how they were presented, in terms of their size and paratextual apparatus. Their treatment illustrates a mixture of continuities and innovation. Rycharde, a metrical romance, was printed by De Worde in 1509 (STC 21007) and again in 1528 (STC 21008), on both occasions in quarto. The title-pages and colophons of the two editions are almost identical, apart from the fact that De Worde styles himself in the earlier one "printer to the king's mother" (Henry VII's mother, Lady Margaret Beaufort, died on 29 June 1509, and for a period before this point De Worde took the opportunity of stressing his connection with her in colophons to the works he printed). ${ }^{13}$ The layout of the text is similar in both editions and the same woodcuts are used throughout, mostly in the same order - although there is one change, perhaps because a cut had gone missing. ${ }^{14} \mathrm{~A}$ woodcut of travelers in a ship used in the 1509 edition was replaced in the 1528 edition with a slightly different version of this scene, a cut used for a number of works after its first appearance in Hawes's Pastime of Pleasure, also printed for the first time in 1509. There is no particular evidence of innovation or experimentation here: rather a pragmatic 'patching up' to keep a tried and tested product looking as it looked before.

The second edition of Malory's Morte Darthur suggests a more alert awareness of what might be commercially attractive. De Worde's first edition of this work, printed in 1498, was one of the big folio-sized volumes produced while his business was still at Westminster: its substantial text derived from Caxton's edition of 1485 and De Worde's innovation in 1498 was to enhance it with

12 On Byddell see STC Vol. III, p. 35; and Blayney (see note 11), p. 285-286. The printer responsible for an edition of Syr Degore (verse; [c. 1535], STC 6470.5) has not been identified.

13 See A. S. G. Edwards and Carol M. Meale, 'The Marketing of Printed Books in Late Medieval England'. In: The Library 6th ser., 15 (1993) p. 95-124.

14 See Edward Hodnett, English Woodcuts 1480-1535. Oxford 1973 [1935], no. 1109. 
a number of woodcuts (STC 802). ${ }^{15}$ The later edition, printed in 1529 (STC 803), remained folio-sized, unusually for this stage in De Worde's career, but also involved a number of changes. The text was modernized and the syntax on occasion changed; most, but not all of the woodcuts from the earlier edition were used and a number of new ones (some of which appear in other works printed by De Worde around this time) were pressed into service. It would be fair to say that De Worde must have regarded this as a premium product and one worth taking care to update. The 1529 edition was also given an unusual and florid full-page version of De Worde's printer's device. ${ }^{16}$ In addition, rather differently from most of the romances printed at this period by De Worde and others, the Morte Darthur was attributed to a named author. Thomas Malory had included his own name in the final section of the work and the printer's colophon draws attention to the fact that "this noble and ioyous boke" was "reduced into Englysshe by the moost wel dysposed knyght afore named".

Most of the romances printed by De Worde were presented without information about authorship - no doubt because these tended to be works of some antiquity, whose authors were simply unknown. Only in the case of the $c .1522$ edition of The Knyght of the swanne or Helyas, which survives in fragmentary form (STC 7571.5), is there likely to have been some indication of the human agency by which the work came into being. If the c. 1522 edition followed the model of De Worde's earlier one, dated 6 February 1512 (STC 7571), it probably included a "Prologue of ye translatour" supplied by De Worde's associate Robert Copland, in which Copland explains that the prose translation (called a "hystory") was commissioned by Edward Stafford, third duke of Buckingham, "lynyally ... dyscended" from the family of Helyas the swan-knight and that he was "cohorted" by De Worde to make a translation from "a true approued" French, printed copy.

The factors which might have prompted De Worde to revisit romances that he had already printed at an earlier point in his career are mostly obscure. The Knyght of the swanne may conceivably have acquired a new topical relevance after 17 May 1521, when Edward Stafford, commissioner of its translation, was executed on the orders of Henry VIII after being tried for treason, but the STC date of its reprinting is approximate (c. 1522) and does not allow for useful speculation. ${ }^{17}$ Since most of these reprinted romances cannot be

15 Hodnett (see note 14), p. 14, 77, 91; D. Thomas Hanks Jr., 'Caxton, de Worde and Malory's Morte Darthur'. In: Reviewing 'Le Morte Darthur': Texts and Contexts, Characters and Themes, ed. by K. S. Whetter and Raluca L. Radulescu. Woodbridge 2005 (Arthurian Studies 60), p. 27-48.

16 McKerrow (see note 1), no. 46.

17 See C. S. L. Davies, 'Stafford, Edward, third duke of Buckingham (1478-1521)'. In: ODNB, online ed., Jan 2008 [http://0-www.oxforddnb.com.catalogue.libraries.london.ac.uk/view/article/26202]. 
assigned to specific dates it is hard to relate them to particular circumstances, but it is possible that the $c .1527$ reprinting of Capystranus (STC 14649.5), the elaborated story of an Italian soldier-saint who led Christian troops against Ottoman forces at the siege of Belgrade in 1456, may have responded to a heightened sense of threat from the east: Suleiman the Magnificent had won the battle of Mohacs in Hungary in 1526 and went on to lead the siege of Vienna in 1529. This context may also have suggested the reprinting of the crusading romance Kynge Rycharde cuer du lyon (STC 21008) and of the historical prose romance The dystruccyon of Iherusalem around 1528 (STC 14519). ${ }^{18}$ Since Malory's Morte concludes with the departure on crusade of the few Arthurian knights left after Arthur's death it is just about possible to interpret its reprinting as associated with the same set of circumstances; but in this case perhaps another prompt was at work: folio editions of the English works were being produced by other printers - the verse romance King Alexander by Richard Faques in (1525?) (STC 321) and many of Chaucer's works, in three volumes, by Richard Pynson in 1526 (STC 5086, STC 5088, STC 5096) - and the production of a new folio-sized edition of the Morte Darthur may have seemed a shrewd commercial move.

\section{New Romances Printed 1520-1535}

The new titles printed by De Worde between 1520 and 1535, insofar as it is possible to determine these, would seem to include only two romances, both in what by this stage may have been the slightly old-fashioned form of verse: The life of Ipomydon, in two editions (c. 1522, STC 5732.5; c. 1527, STC 5733) and Undo youre dore (The Squire of Low Degree; c. 1520, STC 23111.5). Ipomydon was not in itself new - versions survive in fifteenth-century manuscript copies - but one particular text was evidently made available to De Worde by a London mercer, John Colyns, who acquired it in $1517 .{ }^{19}$ Study of the manuscript (London, British Library MS Harley 2252) and of the surviving fragments of the printed editions, suggests that Colyns's copy was prepared for De Worde's printshop by Robert Copland, who added an envoy, at some point between 1517 and about 1524; a date of $c$. 1527 has been proposed for

18 This prose text of the dystruccyon, first printed by de Worde in 1510(?) and reprinted by Pynson in 1513(?), was apparently translated from a French original: see R. E. Lewis, N. F. Blake and A. S. G. Edwards, Index of Printed Middle English Prose. New York 1985, no. 241.

19 This is the B version of Ipomydon (BL MS Harley 2252). 
the second edition. ${ }^{20}$ This is an unusual example of a work which seems to have recommended itself for printing through the simple factor of availability: an acquaintance had a manuscript copy which could be temporarily lent for the printer's use.

The decision to print Undo youre dore (The Squire of Low Degree) is more of a mystery. No sources are known, no manuscript copy of the work has survived and there is no trace of other early printed editions, although it was to be among the romances given a new lease of life by William Copland in the midsixteenth century and appears from references made to it in booksellers' records and other works from $c .1520$ onwards to have been reasonably well known. ${ }^{21}$ It is a curious narrative, different in many ways from other contemporary romances in both verse and prose: it has a disjointed plot, a seemingly disproportionate concern with the material benefits of social advancement and a slightly off-colour preoccupation with the heroine's seven-year worship of a mummified body she supposes to be that of her lost lover. In formal terms, too, it takes romance in unusual directions, devoting much space to dialogue. There may be grounds for supposing that its printing was some kind of experiment on De Worde's part, a testing of the market for romance of a generically innovative mode. The paratextual material that accompanies it in fact makes it look more like a courtly dialogue than a romance. Its title-page employs a woodcut of a richly dressed man receiving a token from a richly-dressed woman; the image is surmounted by a banderole in which appear the words "here begynneth vndo your dore", as if the central moment in the narrative will be a conversation between the two. ${ }^{22}$ The colophon also rounds the work off with the words "thus endeth undo your doore", adding only afterwards "other wise / called the squyer of lowe degre". Other uses of the woodcut, in De Worde's editions of Stephen Hawes's Comforte of Lovers ([1515], STC 12942.5), Chaucer's Troylus and Cresyde (1517, STC 5095) and in the curious alliterative poem The iiii leues of the truelove (1510?, STC 15345), devotional rather than secular, do not suggest that the image carried associations with the range of

20 Carol M. Meale, 'Wynkyn de Worde's Setting-Copy for Ipomydon'. In: Studies in Bibliography 35 (1982), p. 156-171. Sanchez-Martí, Editions of Ipomydon (note 10) proposes a reversal of what has been supposed to be the order in which the editions were printed.

21 See further Julia Boffey and A. S. G. Edwards, 'The Squire of Low Degree and the Penumbra of Romance Narrative in the Early Sixteenth Century'. In: Romance Rewritten. The Evolution of Middle English Romance A Tribute to Helen Cooper'. Ed. by Elizabeth Archibald, Megan Leitch and Corinne Saunders. Cambridge 2018, p. 229-240.

22 Hodnett (see note 14), no. 1009. 
romances invoked within The Squire of Low Degree. ${ }^{23}$ And the woodcut on the verso of the title-page appears elsewhere not in romance narratives but in a satire and a dream-vision: De Worde's edition of Copland's verse translation of The Fyftene Joyes of maryage (1509, STC 15258; fragments of an earlier edition, STC 15257.5 are dated [c. 1507]) and Berthelet's edition of Lydgate's Temple of glasse ([1529?]; STC 17034).

\section{Prose Narratives, Verse novelle, 'Merry Jests'}

Alongside the sporadic reprinting and printing of romances in the years from 1520 to 1535 , De Worde issued a variety of other vernacular narratives, in both prose and verse. Some of these seem to constitute responses to ventures made by continental printers and testify to an evident awareness of what was being printed in other continental centres and most probably bought in London in imported copies. Van Doesborch had been printing prose works of this kind in Antwerp for the English market: Frederick of Jennen in 1518 (STC 11361), Mary of Nemmegen probably in the same year (STC 17557) and The parson of Kalenborowe possibly a little later (c. 1520, STC 14894.5). ${ }^{24}$ Also around 1518, he printed the lyfe of Virgilius and of his deth and many maruayles that he dyd by whychcraft (STC 24828): a work which also existed in French versions such as one printed by Guillaume Nyverd between 1500 and 1519 and another by Jacques Nyverd after 1514. De Worde did not miss the opportunity to get on this bandwagon. He had already produced his own edition of Frederick of Jennen (1517?, STC 11361a) and around 1520 he involved himself in a Parisian collaboration on a French-language version of the life of Virgil entitled Les faictz merveilleux de virgille (STC 24827.5). It was printed in octavo, in Paris, "pour Jean sainct Denis" and presumably also for De Worde, since it carries his device. No English version survives among books printed by De Worde, but the fact that William Copland was able to print the work in English in 1562? (STC 24829), at a point when he was reprinting other of De Worde's narratives and romances, may mean that he had access to a translation later printed by De Worde of which all trace is now lost.

Certain other narratives seem to have recommended themselves for publication on the basis of commercial success in continental editions. Two separate

23 Hodnett (see note 14), no. 1120. The speech scrolls contain text only in The iiii Leues of truelove: [woman:] "holde this a token y yyve [yvvye?]" and [man:] "for your sake I shall it take". Copland's edition reproduces the title-page woodcut but not the one on the verso.

24 [For Van Doesborch, see also the contribution by De Bruijn in the present volume, p. 110-113.] 
tales from Boccaccio's Decameron, translated into English verse by William Walter, probably come into this category. Ye hystory of Tytus \& Gesyppus survives in an edition from 1525 (STC 3184.5) and The amerous hystory of Guystard and Sygysmonde from 1532 (STC 3183.5). Possibly because the two stories were considered slightly higher-status texts than other kinds of narrative, it was seen fit to include some information about their translator. According to the title-pages of the two novelle and the other of his works printed by De Worde, The spectacle of louers ... a lytell contrauers dyalogue bytwene loue and councell ([1533?], STC 25008), he was "somtyme servaunte to syr Henry Marney knyght chaunceler of the duchy of Lancastre". It would be useful to know more about Walter, but little biographical information has survived. ${ }^{25}$ Marney (1447-1523) was a member of the privy council under Henry VII and Henry VIII and had interests in both Essex and London, where his first wife was a daughter of an alderman and merchant taylor and a member of a prominent family. ${ }^{26}$ His servant William Walter may have had London connections of his own and it is possible that an acquaintance with Robert Copland, who had been providing translations for De Worde since c. 1505, first brought him to the printer's notice: Copland supplied a verse framework for Walter's Guystarde translation of $c .1533 .^{27}$

The title-pages of both Tytus and Gesyppus and Guystarde and Sygysmonde proclaim that the English versions are translated from Latin rather than from Boccaccio's Italian. Likely sources have been identified in Latin prose versions of the stories made respectively by Filippo Beroaldo (Mythica historia de Tito Gisippoque) and Leonardo Bruni, also known as Leonardo Aretino (De duobus amantibus Guiscardo et Sigismunda) ${ }^{28}$ It is worth noting that the Latin versions of both stories circulated independently outside the context of either the

25 A. S. G. Edwards, 'Walter, William (fl. c.1525-1533)'. In: ODNB, online ed., Jan 2008 [http:// 0-www.oxforddnb.com.catalogue.libraries.london.ac.uk/view/article/28641].)

26 James P. Carley, 'Marney, Henry, first Baron Marney (1456/7-1523)'. In: ODNB, online ed., Jan 2008 [http://0-www.oxforddnb.com.catalogue.libraries.london.ac.uk/view/article/70724]. 27 A William Walter was admitted as clerk of the Exchequer in April 1524 (London, The National Archives SP 46/139/fo171) and in 1498 a William Walter, citizen and grocer of London, with his wife Ellen, claimed a debt from Humphrey Medwall, citizen and goldmith (TNA C 241/275/334). For details of Copland's biography, see Erler, Copland (note 10), Introduction.

28 See Early English Versions of the Tales of Guiscardo and Ghismonda and Titus and Gisippus from the Decameron. Ed. by H. G. Wright. London 1937 (Early English Text Society, 205), where the earliest printing of the Mythica historia is dated 1491, in the context of Orationes et poemata (Bologna; GW 4144), and the first independent edition of the story c. 1498 (Leipzig; GW 4501). There is some further brief discussion in Guyda Armstrong, The English Boccaccio: A History in Books. Toronto 2013, p. 163-164. 
Decameron or of other works by their Latin translators. Both went through a number of continental editions and the story of Guystard and Sigismond had an especially wide circulation, since it became available in a translation by Beroaldo as well as in Bruni's version. ${ }^{29}$ De Worde's editions paid some attention to giving these stories visual appeal. The title-page of Tytus and Gysippus presents some factotum figures, here labelled with banderoles, who appear countless times in De Worde's books, doing service not just for narratives but also for interludes and plays, dialogues and debates, misogynist works and treatises of various kinds. ${ }^{30}$ The four cuts in Guystarde and Sygysmonde, the later of the two works to be printed, may have been specially made for this narrative, since they do not appear in other of De Worde's books and are closely tied to the substance of the text. ${ }^{31}$

Rather different from these more up-market narratives are the short comic tales in verse that De Worde printed between 1520 and 1535, adding to a line which he seems to have been quite keen to develop after his move from Westminster to Fleet Street: works falling into this category from the decade after the move include The smith that forged him a new dame ([c. 1505], STC 22653.5), a lytell geste of Robyn hode ([1506?], STC 13689) and a mery geste of the frere and the boye ([1510-13], STC 14522). De Worde was not the only printer to issue works of this kind - Robin Hood narratives and other comic tales were produced sporadically by Pynson and others - but De Worde's special interest is perhaps demonstrated in his association with a greater range of titles. Relevant to the date limits of this discussion are a mery iest of the mylner of Abyngdon ([1532-4?], STC 78) and a lytell propre ieste called cryste crosse me spede ([1534?], STC 14546.5). Cryste crosse me spede, of which only two leaves survive, recounts the substance of a gossips' feast in an ale-house and is one of a number of comic anti-feminist pieces, sometimes in the form of complaint or dialogue rather than narrative, among De Worde's publications. ${ }^{32}$ The mylner of Abyngdon is a slightly more sophisticated fabliau; described on its title-page as "a mery iest / of the mylner of Abyngton with his / wyfe and his doughter and / two poore scholers of / Cambridge", it is essentially a reworking of the tale of the Reeve from Chaucer's Canterbury Tales. The action is given a new setting (Abingdon in Cambridgeshire rather than Trumpington) and Chaucer's

\footnotetext{
29 USTC lists 115 editions.

30 Driver (see note 6), p. 49-75.

31 Hodnett (see note 14), no. $927 \mathrm{a}-\mathrm{d}^{\star}$.

32 See Julia Boffey, 'Wynkyn de Worde and Misogyny in Print'. In: Chaucer in Perspective: Middle English Essays in Honour of Norman Blake. Ed. by Geoffrey Lester. Sheffield 1999, p. 236-251.
} 
pentameter couplets are replaced with twelve-line tail rhyme stanzas. Certain elements of the narrative are given new twists: the two students are brothers, for example, and they search for wheat to alleviate their widowed mother's poverty; and at the end of the tale the thieving miller, unlike his counterpart in Chaucer's story, appears to regret his actions. ${ }^{33}$ Although Chaucer's name is not mentioned in the surviving portion of this tale, its relationship to the Reeve's Tale would have been clear to anyone acquainted with The Canterbury Tales and was perhaps assumed to be one of its 'mery' qualities.

The mylner of Abyngdon suggests possible intersections between higher and lower status reading matter that are often overlooked in discussions of premodern culture predicated on the notion of distinct audiences for 'elite' and 'popular' literature. Such intersections may also be evident in De Worde's printing of John Skelton's The Tunning of Elinor Rumming (1521?, STC 22611.5), a verse account of the goings-on in the premises of a fearsome female brewer and tavern-keeper. In both content and spirit this piece anticipates Cryste crosse me spede and like that it probably took the shape of a small singlegathering pamphlet or booklet. The edition attributed to De Worde survives only in seriously depleted form, ${ }^{34}$ but a full text is preserved in a collection of Skelton's verse printed c. 1545 (STC 22598), where its scabrous humour is thrown into relief by a series of witty Latin colophons. In this and other later editions Skelton's authorship is made plain at both the start and end of the poem ("per Skelton laureat”, "Quod Skelton Laureat”, "Laureati Skeltonidis in despectu malignantium distichon"), but the fragmentary nature of the edition attributed to De Worde means that it is now impossible to know whether or not such phrases were present in it. De Worde did not miss opportunities to mention authors' names, drawing attention to the "preclared and famous clerke Geffray Chaucer" on the title-page of his 1530 edition of The Parliament of Fowls, for example (STC 5092), ${ }^{35}$ and naming Stephen Hawes and William Neville in his editions of their works (Hawes's Example of Vertue, 1530, STC 12947; Neville's Castell of Pleasure, [1530], STC 18475), but Skelton's Tunning of Elinor Rumming is unusual among "mery jests" for its connection with a named

33 The final leaf is missing from the single surviving copy.

34 See R. S. Kinsman, 'Eleanor Rediviva: Fragments of an Edition of Skelton's Elynour Rummyng, ca. 1521'. In: Huntington Library Quarterly 18 (1955), p. 315-327.

35 The Parliament, perhaps newly designed for this edition, gives prominence to Chaucer's name on the title-page and draws attention to his status as auctor with an author-woodcut used mainly elsewhere by De Worde on Latin grammars: see Hodnett (see note 14), no. 926. Rastell's 1525? edition of the poem (STC 5091.5) had rather differently used a woodcut of a bird and some eggs (Hodnett (see note 14), no. 2286). 
author; and mostly with works of this kind De Worde (like other printers) was unconcerned to supply details of authorship or source.

\section{Narratives in Context}

The slightly odd assortment of works discussed in the category above - prose narratives, verse novelle, 'merry jests' - has its own point to make in the larger context of the output of De Worde's later career. By this point a pattern seems to have been established of reprinting works that were to hand and only occasionally taking any new initiatives. Such new moves as were made in relation to narratives usually involved texts that were short: Ipomydon stands out as an unusual departure. Practices in relation to size of book and paratextual apparatus tended to be conservative. In the earlier part of his career, during the years when he seems to have actively wanted to establish a market for verse romances and to build on Caxton's established success with prose romance, De Worde printed a number of long verse romances incorporating many woodcuts (some newly designed, others from stock) as attractive features. In his final decade, although the illustration of the 1529 Malory suggests a degree of continuing interest, he was seemingly less concerned with this aspect of marketing and design innovation. Among narrative works whose title-pages survive, factotum figures are much in evidence. Even in works for which new cuts might have been supplied, such as Guystarde and Sygysmonde, the labour involved would hardly have been extensive. The "mery jest" of the Mylner of Abyngdon has a title-page woodcut which does not survive in any other contexts, but it simply depicts a mill, with no people visible, and could well have been found somewhere in existing stock. ${ }^{36}$

Like most of the books de Worde printed, works of narrative literature appeared by this stage almost always in quarto-sized editions: the 1529 edition of Malory stands out as one of very few folio-sized books printed at this stage in his career, ${ }^{37}$ and Les faictz merveilleux de virgille as an unusual experiment in

36 Hodnett (see note 14), no. 879.

37 De Worde seems to have opted for quarto at an early stage, for example reducing the prose romance Paris and Vienne to this format in 1505 (STC 19207a and 19208) in comparison with the folio-sized editions printed by Caxton (1485, STC 19206) and Leeu (1492, STC 19207). William Bonde's Pilgrimage of perfection, (23 February 1531, STC 3278) is one of the few other folio-sized books printed in De Worde's later career. [For the preference for octavo in Denmark, see the contribution by Richter in the present volume, p. 330. For French Arthurian romances in folio, see the article by Montorsi, p. 174. For German preferences, see the contribution by Bertelsmeier-Kierst, p. 37.] 
octavo (a format occasionally used for grammars, such as Lily, de octo orationis, STC 15601.7, schoolbooks like Terence, Vulgaria, STC 23908, and for various Latin handbooks for priests). The preference for quarto was presumably determined in part by economic factors, but it may also reflect the fact that this is a 'saleable' size of book, easy for purchasers to hold and read. Few of de Worde's narratives from these years have significant paratextual apparatus of any kind and in layout they are strikingly simple, especially in comparison with his much more complicatedly conceived schoolbooks and grammars. ${ }^{38}$ Some small degree of effort may have gone into the generic distinctions that might be signaled in the words used on the title-pages or in colophons to narrative works. Like other early printers, de Worde used "history" of a number of the romances and narratives he printed, very occasionally diversifying into "treatise". 39 "Mery jest" is used rather more specifically, though, as if this was somehow felt to be a more distinct category. From earlier in de Worde's career the term is used of How the plowman learned his paternoster ([c. 1510], STC 20034), a lytell geste of Robyn hode ([1506?], STC 13689) and the frere and the boye ([c. 1510], STC 14522); and from the period under consideration here also of Cryste crosse me spede and The mylner of abyngdon.

Statistics suggest that narratives formed only a small proportion of De Worde's output during these years. This discussion has made particular reference to eighteen works, a small number of which were printed more than once during the period 1520-1535. STC figures indicate that the total number of editions printed by De Worde during this period (sometimes in collaboration with others) reaches well over 300. Narrative works thus constituted only a very small part of regular business - barely one title a year - most of which was by this stage taken up with grammars and schoolbooks of various kinds, some of which went through multiple successive editions. De Worde may have retained an interest in printing narrative literature in the final decade or so of his career, but he was hardly actively seeking to develop new initiatives in this area. The works of this kind that he brought into print for the first time during these years are short works of the "mery jest" kind and novelle like the Boccaccio translations. He seems not to have wanted by this stage to venture seriously into Chaucer and Lydgate, printing only short works by each. He was happy to reprint the works of Stephen Hawes, with whom he probably had personal connections earlier in career; and he perhaps printed William Neville because

38 See, for example, his editions of Robert Whittinton's Verborum praeterita \& supina (1521, STC 25558 and many reprints up until 1533).

39 The 1510 edition of STC 17841.3, ye byrth \& prophecy of Merlin calls it a "treatise" but because the 1529 edition is fragmentary it is not possible to know if the term was repeated there. 
Neville worked with Copland and Copland had edited the earlier edition. De Worde apparently responded to 'prods' of various kinds: perhaps printing The Parliament of Fowls because Rastell had printed it and because Pynson had brought out a whole volume of Chaucer's minor poems; printing Malory's Morte Darthur for the second time in 1529, in folio, because Faques had recently printed a long new romance, King Alexander, in a folio edition (1525? STC 321). Although his own energies may have flagged slightly in his later years in relation to English narrative works, it is nonetheless striking that a number of his associates - people who had worked for and with him, or used his types helped to start their own businesses with the printing of short romances and jests: exactly the kinds of work which De Worde had at an earlier stage helped to put on the map in printed form. The commercial attractions of these works continued to be recognized.

\section{Bibliography}

Armstrong, Guyda, The English Boccaccio: A History in Books. Toronto 2013.

Bennett, H. S., English Books \& Readers 1475 to 1557. Cambridge 1970 [1952].

Blake, N. F., 'Wynkyn de Worde: the Early Years'. In: Gutenberg Jahrbuch (1971), p. 62-69.

Blake, N. F., 'Wynkyn de Worde: the Later Years'. In: Gutenberg Jahrbuch (1972), p. $128-138$.

Blayney, Peter W. M., The Stationers' Company and the Printers of London 1501-1557. 2 vols, Cambridge 2013.

Boffey, Julia, 'Wynkyn de Worde and Misogyny in Print'. In: Chaucer in Perspective: Middle English Essays in Honour of Norman Blake. Ed. by Geoffrey Lester. Sheffield 1999, p. 236-251.

Boffey, Julia and A. S. G. Edwards, 'The Squire of Low Degree and the Penumbra of Romance Narrative in the Early Sixteenth Century'. In: Romance Rewritten. The Evolution of Middle English Romance. A Tribute to Helen Cooper. Ed. by Elizabeth Archibald, Megan Leitch and Corinne Saunders. Cambridge 2018, p. 229-240.

Carley, James P., 'Marney, Henry, first Baron Marney (1456/7-1523)'. In: ODNB, online ed., Jan 2008 [http://0-www.oxforddnb.com.catalogue.libraries.london.ac.uk/view/article/ 70724].

Davies, C. S. L., 'Stafford, Edward, third duke of Buckingham (1478-1521)'. In: ODNB, online ed., Jan 2008 [http://0-www.oxforddnb.com.catalogue.libraries.london.ac.uk/view/arti cle/26202].

Driver, Martha W., The Image in Print: Book Illustration in Late Medieval England and its Sources. London 2004.

Edwards, A. S. G. and Carol M. Meale, 'The Marketing of Printed Books in Late Medieval England'. In: The Library 6th ser., 15 (1993), p. 95-124.

Edwards, A. S. G., 'Walter, William (fl. c.1525-1533)'. In: ODNB, online ed., Jan 2008 [http://0-www.oxforddnb.com.catalogue.libraries.london.ac.uk/view/article/28641]. 
Erler, Mary C., 'Wynkyn de Worde's Will: Legatees and Bequests'. In: The Library, 6th ser., 10 (1988), p. 107-112.

Hanks, D. Thomas Jr., 'Caxton, de Worde and Malory's Morte Darthur'. In: Reviewing 'Le Morte Darthur': Texts and Contexts, Characters and Themes. ed. by K. S. Whetter and Raluca L. Radulescu. Woodbridge 2005 (Arthurian Studies 60), p. 27-48.

Hellinga, Lotte, William Caxton and Early Printing in England. London 2010.

Hodnett, Edward, English Woodcuts 1480-1535. Oxford 1973 [1935].

Kinsman, R. S., 'Eleanor Rediviva: Fragments of an Edition of Skelton's Elynour Rummyng, ca. 1521'. In: Huntington Library Quarterly 18 (1955), p. 315-327.

Lewis, R. E., N. F. Blake and A. S. G. Edwards, Index of Printed Middle English Prose. New York 1985.

McKerrow, R. B., Printers ' and Publishers 'Devices in England and Scotland, 1485-1640. London 1913.

Meale, Carol M., 'Wynkyn de Worde’s Setting-Copy for Ipomydon'. In: Studies in Bibliography 35 (1982), p. 156-171.

Meale, Carol M., 'Caxton, de Worde and the Publication of Romance in Late Medieval England'. In: The Library 6th ser., 14 (1992), p. 283-298.

Moran, James, Wynkyn de Worde: Father of Fleet Street.Ed. by Lotte Hellinga and Mary C. Erler, with a preface by John Dreyfus. London 2003 [1976].

Neville-Sington, Pamela, 'Pynson, Richard (c.1449-1529/30)'. In: ODNB, Oxford 2004; online ed., Jan 2008 [http://0-www.oxforddnb.com.catalogue.libraries.london.ac.uk/view/article/ 22935].

Robert Copland: Poems.Ed. by Mary C. Erler. Toronto 1993.

Sánchez-Martí, Jordi, 'Wynkyn de Worde's Editions of Ipomydon: A Reassessment of the Evidence'. In: Neophilologus 89 (2005), p. 153-163.

Sánchez-Martí, Jordi, 'Robert Copland and The Lyfe of Ipomydon'. In: Notes and Queries 55 (2008), p. 139-142.

Sánchez-Martí, Jordi, 'The Printed History of Middle English Verse Romances'. In: Modern Philology 107 (2009), p. 1-31.

Sánchez-Martí, Jordi, 'Illustrating the Middle English Verse Romances'. In: Word and Image 27 (2011), p. 90-102.

Wright, H.G. (ed.), Early English Versions of the Tales of Guiscardo and Ghismonda and Titus and Gisippus from the Decameron. London 1937 (Early English Text Society, 205). 
